\title{
THE RESISTABLE RISE OF DONALD TRUMP
}

\author{
Reginaldo C. Moraes ${ }^{1}$
}

This article is a collection of the author's previous contributions in his weekly column of Jornal da Unicamp. The argument is organized as it follows. First, I will discuss the reasons for Trump's victory including the alleged worker's turn to the right. Next, I portray the behavior of Brazilian media in this debate. Finally, I try to frame Trump's ascension within the logic of a neoconservative strategy.

\section{ROAD TO SUCCESS}

As soon as Donald Trump won the election, immediate interpretations referred to it as an earthquake in American politics, an ultraconservative electoral turn. In the so-called mainstream media, analysts seemed to awake after an exercise of long and self-imposed hypnosis. Large American (and Brazilian) newspapers spent a long time making audiences believe that a "more of the same" victory would occur with the "inevitable" Hillary Clinton. Apparently, they believed in what they were selling and drastically fell short of their expectations. Confusion of the following moment corresponded to the certainty and security that reigned previously.

It is worth listing some of the myths and inaccuracies surrounding assessments of the Republican candidate's victory. Among them, I highlight the following.

1) There was a conservative revolution and an unexpected and unprecedented growth votes on the Republican right.

2) The so-called "white working class" switched from democrat left to the trumpist ultra-right.

3) Steve Bannon and his computer specialists conducted miraculous operations providing a new domain for inflammatory populist ideas and determining Trump's victory.

Several questions remained underdebated or undiscussed during these early analyses. For instance:

1) What was the role of perception manipulation techniques employed by neoconservatives?

2) What was the role of the so-called "dog whistle politics"? "Dog whistle politics" refers to conquering hearts and minds through coded and diversionist signs so to legitimize unequal policies, such as racism, sexism and "values politics".

1. Professor at Campinas State University (Unicamp) and Researcher at the INCT-Ineu. E-mail:<rccmoraes@gmail.com>. 
3) What was the role of Petencoastal churches and their media channels' steady and solid work to shape avarege Americans perceptions? A few decades ago, these churches developed a very efficient semi-presential educational system, combining weekly worship with radio and TV broadcasts. During the 2000s, these institutions developed a kind of neoconservative church, Fox News, a very relevant channel to shape the country's sentimental and ideological agendas. One of the main advantages of evangelicals according to a Democratc writer is that they have usual places to meet two days before the election.

4) What was the role of electoral absenteeism, mainly by democratic or "leftist" segments, such as the young, social minorities and the poor? In fact, on the last ten years, one of the main concerns of the ultra-right wing was precisely forcing abstention of these voters - the "so-called inconvenient" or inclined to the Democratic Party -, especially by invalidating in any possible way their right to vote.

5) What was the role of redesigns of electoral districts to shape electoral colleges - also known as Gerrymandering? Republicans are, by far, ahead of the Democrats on these techniques and they manage to strongly interfere in the composition of legislative and executive brances, national congress and electoral colleges choosing the president. $^{2}$

\section{Many are called, but few are voters}

The first answer we need from existing date is who voted and who abstained the most? Generally, abstention levels in US elections are usually high, but they do not equally affect all segments of income, race or ethnicity. At a presidential election, an average of $40 \%$ of voters do not show up. On other elections, even more so. Local elections have an average of $20 \%$ to $30 \%$ of participation and more than $70 \%$ of abstention.

Data indicates clearly that lower income people, the youth and ethnic minorities have the largest abstention rates. These are precisely the social segments that should do it the least since they must defend their rights. Looking at data from this election (which reinforce those of previous ones) one finds upper income segments are overrepresented among actual voters. Apparently, lower income people are those who give up most before trying. They must have their reasons for that, right? These data illustrates how the two candidates obtain a disproportionate share of their votes from those with a reasonable income and not from the unfortunates.

2. A rather surprising example is in this video: <https://www.nytimes.com/video/us/100000005921047/gerrymanderinghistory-future.html>. 
One must reinforce how important it is to know to only voter's profiles but who votes in each candidate in particular. One must also know who votes and who gives up voting under special circumstances. A largely difused Pew Research poll survey asked and answered the following question: "Who helped the most to elect Trump in 2016? The non-voters" (Brittany, 2018). This was fatal. Research shows that non-voters are likely the youngest, the least educated, the least wealthy and the non-white. The Democratic Party has an overwhelming dominance over this voter profile. More than just choosing Donald Trump's name in the ballot box in the Rust Belt states dominant to Hillary's defeat, several voters simple gave up voting for the Democratic Party differently from what they had done in previous elections.

\section{Which "working class"?}

Now let us move to the allegeded working class turn to a conservative ideology. The heart of America's industry, the Manufacture Belt became the "Rust Belt". Hence, job losses and destruction of communities led several angry blue-collar workers to move from Democratic Party to Trump. This would have been a slap in the face of the liberal, globalist, perfumed and cosmopolitan elite. This argument has several elements of truth - such as the destruction of hope and the emerging hopelessness environment, for example. However, as I will show bellow, this assessment has flaws in both its conclusion and base data.

The second issue is to specify, as much as possible, what is called "a white working class" in order to know how much it refers to workers and to white people. A common indicator to identify this social segment is education - since the working class does not have college education. Another one is income, that is receioving the average or below the national average.

Now, there are millions of Americas, who do not have college degrees, and still could hardly be considered working class. For example, there are about seventeen million small business owners, who do not have college degree. By 2016, a National Small Business Association survey showed that $86 \%$ of small enrepreneurs were white and $92 \%$ vote regularly in national elections. They are almost a permanent electorate, with very low abstention. Their annual earnings were around US $\$ 112,000$ compared to the US average of US $\$ 48,000$.

A columnist suggests the following calculation: add to these businesspersons their wives and, possibly, an adult child. This classic small bourgeoisie could easily account for the 29 million votes of "diploma holders" who voted for Trump. There is no need to appeal to the contingent of "blue overalls" workers.

On the other hand, it is hard to argue that a once left wing (or at least center-left) working class suddenly jumped to the ultra-right competitor. After all, 
during recent decades, something like $40 \%$ of union members and their families have voted for the Republican party and not for the Democratic Party that their unions support - there have already been "Nixon Democrats" and even more "Reagan Democrats." Has there ever been such displacement? Yes, apparently there was in some regions. Nevertheless, there was a much more significant shift: a dropout from voting for the Democrats or, more exactly, for Hillary, for reasons we will try to understand later in this article.

\section{The right campaign, in the right places}

If we answer the central question of "what has Trump disputed and won?", then, it becomes less of a puzzle how he won.

Trump definitively was not seeking popular votes. He clearly gave up campaigning in some places since it no longer mattered losing by a 70 -to-30 or 60-to-40-vote difference in states such as California, he must have considered. Whatever the outcome, all delegates would have gone to Hillary after all. Trump focused where he should. Using different kinds of "big data", including the infamous Cambridge Analytica, he divided his electorade into thrity types and addressed them with stlyzed messages. He bet on the right states in which he had bigger chances to win delegates of the electoral college.

Trump's digital campaign chief, Brad Parscale detailed the procedures. In fact, using a platform like Facebook was a gold mine. Not only because it reached a lot of people, but also due to the fact that each reader's "click" provided the sender information on the viewer electoral preferences.

So Trump's team could do massive and increasingly "personalized" advertising experiments. It could "customize" the candidate according to the elector profiles. This was a more efficient survey than any conventional one faster, cheaper, produced with the authorization and even with the participation of the "interviewee". Parscale estimates that he has manipulated more than 200 million profiles, with 5,000 bits of data per profile.

Thanks to this technology, and to simple and more or less conventional elements, such as redesigning electoral districts, Trump's victory was defined without Hillary and the media perceiving anything. Hillary beat Trump in total votes -66 to 63 million, but lost in the number of delegates at the electoral college, which is what really matters. Plus, the Democratic Party candidate lost the delegates of four key states of their old industrial base - Pennsylvania, Ohio, Michigan, Wisconsin. If Hillary had won an additional 25,000 votes in each of those states, she would have won the election. Those votes did not go for Trump he basically repeated Mitt Romney's performance four years earlier. They were the "it makes no difference vote". Because in doing that, too, Trump's campaign did 
"the right thing". His strategists followed a pragmatic reasoning: "if it's harder to win over voters for Trump, let's try to demoralize Hillary's potential voters."

It also worth noting where Hillary Clinton's "three million plus votes" were located. Half of them were concentrated in New York City! The rest was in California. In these places, Hillary had a widespread - but redundant and useless - victory as defined by the result, in the sum of delegates of the electoral college.

Indeed, declining in quality jobs linked to industry, weakening trade unions, emerging horrible and alienating jobs, and reducing tax transfers to cities, created not only "angry whites" but also enraged Latino, Black and Asian men and women. A slightly wider and more differentiated universe. They had reasons not to want to see the Democrats as their representatives. Hillary's e-mails and conversations leaked on the eve of the election only fueled the pre-existing bonfire.

All this seems to corroborate Olga Khazan's comment in an article for The Atlantic, in 2018, commenting on academic research about the fact. She argued:

people voted for Trump because they were apprehensive, not because they were poor. A new study found that Trump's voters were not losing income or jobs. Instead, they were worried about their place in the world ... Trump's supporters felt threatened, frustrated, and marginalized - not economically but on an existential level (Kazan, 2018).

Some remember the phrase of Clinton's advisor: it's the economy, stupid! Yes, the economy does cause dramatic situations. However their effects are not necessarily "economic" as well.

\section{The strength of material conditions ... and of expectations}

Recently, at a seminar in India, Hillary recorded a symptomatic assessment:

the part of the United States where I won represents the share of the country that thrives economically. I have won in places that account for two-thirds of America's gross domestic product so I have won optimistic, diversified, dynamic places. Areas that are looking ahead. And the whole other campaign - "Make America Great Again" - was looking backwards.

That is not exactly false. The problem is that "deplorables" continue to exist. A country is not only composed by its advancing and enriching parts, but it also includes - and especially excludes - those who fall behind. Especially because many of those who advance do so at the expense of those who fall behind. Not only because "they are better" or more dynamic - maybe they are a bit "smarter", in some sense - but also because the economic policy matrix makes them come out ahead. 
Hillary and the Democrats might have had a chance to reverse that situation. Some analysts suggest that Sanders would have had a better chance because he embodied better an idea of "state as a solution". That could be true since Hillary was overly committed to the perverse effects of an economic policy that encourages globalization and financialization.

On the eve of the elections, some posts and talks of Hillary were leaked, showing her predilection for these areas (mainly for the banks). There were compromising phrases that sounded something like this: "honorable bankers, I will criticize you in public and work for you in my cabinet." This could not have been more disastrous - and was cleverly used by the communicators of Trump's campaign. These elements were cleverly used by Steve Bannon, replicating techniques used by the Brexit campaign and further used by Bolsonaro's campaign in Brazil. ${ }^{3}$

Bannon's efficient communicational and computer operation ended Hillary's candidacy. Differently from Trump's, Hillary's campaign had strongly built itself within the Democratic bureaucracy and among campaign funders, but at the expense of pride and contempt for the democrats in overalls. Thus the death of Hillary's campaign occurred slowly over time.

\section{BRAZILIAN MEDIA PLAYS THE TRUMPET}

Temer government has considerably changed Brazil's foreign policy. His first measures included an attempt to build a closer partnership with the US and its large corporations, opening up the control of mineral wealth (such as the pre-salt oil) to foreign capital and offering promises of vast public investments to foreign contractors since national firms had been practically decimated by the Lava Jato operation. Disregard shown towards southern partners, in particular to Mercosur and the BRICS, also points in this direction.

Now, even before taking office, the elected government in 2018 shows similar inclinations. But there are some differences, perhaps resulting from different alignments in the heart of the empire.

Politically, Temer government was apparently more comfortable with the allegeded victory of Hillary Clinton, believing it would accelerate bilateral trade agreements. Temer's foreign minister, José Serra, publicly stated this alignment by stating that Hillary's victory was expected and that Trump represented such a "nightmare" that it could not and should not occur, a phrase that resulted in embarrasement later on.

3. There is a very didactic video explaining these operations: <https://vimeo.com/295576715>. 
The Bolsonaro government seems to have another inclination. Trump is not only his inspiration, it seems to be, more and more, his magnet, his center of strength. Similarly, the new government also has differences in its relationship to the local mainstream media.

During the American election campaign, the Brazilian government and the mainstream press (dominated by six families in Brazil) "cheered" for Hillary in an evident and confident manner. This support was so big that it obscured their ability to analyze and the prudence to protect themselves in the face of an adverse outcome. To this day, a large part of this media has been working to delegitimize Trump's victory - with "journalistic" scenarios that suggest "impeachment" in the future.

The government, of course, had to be more subtle. Trump was not in Temer government's dreams, but that did not authorize it to enter in conflict with the newly elected head of state. The truth is that Trump has created a great deal of uncertainty in the international arena, and more specifically, in Brazil's foreign policy. Uncertainty is the hallmark of the new times in foreign policy, far from the "business as usual" represented by Hillary Clinton. Perhaps this explains, in part, the back-and-forth moves of the mainstream media.

\section{Brazilian press dreamed of Hilary and woke up with Trump}

As previously mentioned, Brazilian mainstream media's preference of the for the Democratic candidate was perceptible. Both news programs and "opinion columns" always showed (before the election and afterwards) a remarkable exercise of confusion between desire and reality. A reporter for the Globo network, the country's largest info-entertainment chain, published a tweet that sparked a stir among the editors: "In Brazil there is no coverage of the American elections. There is a fan club cheering for Hillary Clinton's victory."

He was a lonely voice, or almost. The day after the results, the newspaper $O$ Globo issued a very harsh editorial against the new president (Editorial, 2016).

The Brazilian media was not very different from the American media in this blind pro-Hillary alignment. During the the primaries Trump was portrayed as a star of the world of entertainment, something grotesque - an image similar to the one New York Times painted when one of its top journalists said the eccentric campaign would be confined to the newspaper's entertainment section.

In Brazil, columnists obsessed with the image of "global" modernity portrayed a pattern of self-deception. Such is the case of Marcos Troyjo, a columnist of Folha de S.Paulo, who also plays the role of sociologist at Columbia

4. Available in: <https://twitter.com/giocondabrasil/status/789235076668264448>. 
University. After framing Trump in the show-business dimension, he declared: "Donald Trump's rise is not in the public interest, but surely attracts the public's interest." (Troyjo, 2016). As a self-proclaimed interpreter of this supranational public interest, the columnist roasted the Republican candidate. He admitted a remote possibility of surprises, but in fact he seemed comfortable with the dominant attitude: "the bet is always that at the 'final moment', the American voter will say 'well, that's enough fun for now. Let's vote for boring, predictable and more-of-the-same Hillary Clinton." If the reverse were to happen, he says, we will have the world "on the verge of a nerve crisis." That is not what happened.

Mocking Trump's eccentric proposals, Troyjo defended the Democratic candidate in relation to the dramas of American domestic politics. It would bring, for example, "a denser message on gun control", since "easy access to guns in the United States is the common element found in all mass shootings".

Clovis Rossi, a long-standing international correspondent, commented on a survey of business leaders and suggested that the repudiation of these "elites" to Trump probably represented the opinion "of the continent": "lacking scientific data, let us stick to the opinion of 'leaders', who, moreover, seems extremely sensible in rejecting Trump" (Rossi, 2016). Since the opinion of business leaders seemd to be reasonable from the reporter's point of view, he assumes that it is also true. As usual, we tend to identify reasons of others we do not understand or accept as irrational.

This view largely marginalizes the so-called "deep-America", transfiguring it into a "superficial-America". Trump is accused of making "superficial" diagnoses and treatments for America's illness - when he, for example, appeals to the sense of loss of a decimated-by-globalization "white working class". "Deep America", for globalists, is superficial, a world easily accessible to populists and demagogues. According to Troyjo, Trump "takes advantage of domestic economic dissatisfaction, such as the sense of loss of jobs that the less qualified industrial laborers experience in the US, to disseminate simplistic foreign policy solutions based on prejudice or faulty diagnosis."

In short, few Brazilian analysts have been able to understand the real depth of the crisis that a large part of the US wage-earner faces.

\section{What is in evidence is not only Trump}

Which could be the motivations among Brazilian authorities, analysts and journalists, to soften the electoral duel with so little support on evidence? First, we must consider the influence of American media coverage. This media was very favorable to Hillary and pointed her as the winner until the very day of the election. Second, we must highlight the neoliberal bias of the Brazilian press, dominated by few families and analysts with a long-established ideological 
position. This ideological position was more in line with the proposals and ideals represented by Hillary Clinton, particularly in the economic and social fields. Finally, Donald Trump's attacks on the Latino population may have had some influence on the preferences of Brazilian analysts.

Despite Trump's victory, most of the Brazilian media decreed Hillary as the "moral winner" of another election. The vast majority of headlines focused on the fact of Hillary defeating Trump in popular voting, implying that the issue to be overcome was the American electoral system. The same phenomenon was observed during the dispute between $\mathrm{Al}$ Gore and Bush Jr. at the beginning of the millennium. The fact that the Brazilian media doubting the American electoral system shows incomprehension of the US federal system, quite different from the one existing in Brazil. It also shows a condescending treatment with the American electoral system as it is not a direct representation model - supposedly more democratic in the eyes of most analysts. As Lucia Guimarães, a journalist at in Estadão, argued reasons for the defeat of their favorite candidate could be "found in the "cloud"": "Trump is the first president elected by extremism stimulated by digital culture" (Guimarães, 2016). According to this interpretation, an unfamiliar machine - the uncertain cloud of internet gossip -, would have victimized Hillary.

In short, the coverage of Brazilian press says more about the press and its inclinations than about the facts narated. Since pro-Hillary American media heavily influenced it, Brazilian media was unable to comprehend in depth dilemmas of both American society and the US electoral system. Therefore Brazilian media was not only surprised by Trump's victory but also forced entangle itself in unconvincing explanations to justify the rise of an outsider of aggressive speech.

\section{SUMMARY}

Trump's election shows a conservative advance, but not exactly electoral gains to this agenda. Electoral gains were relative since the Republican electorate, after all, did not change much from last elections. Trump's election was, however, a successful operation based on other indicators. Firstly, Republicans were able to take advantage of reducing electoral enthusiasm towards Democrats, notably regarding Hillary Clinton. They succeeded in provoking defections of Democratic voters by a variety of instruments. One of them was indirect and negative campaign demonizing opponents' platforms. US law allows civil organizations to receive unidentified donations for "political education" as long as it is not explicit advertisement for a party or candidate. Another important weapon was to avoid people to vote, using fatigue or legal veto strategies (in some 
states, there was a voter-annulment industry based on claims to combat electoral frauds, which avoided registration of potential inconvenient groups, such as the young, blacks or latinos). Finally, there were other tactics, such as making voting uncomfortable. In the US, elections take place on a regular working day. Election after election, tactics such as reducing the number of locations for voting or changing their addresses increased voter confusion and absence, creating long queues and time wasting.

All this adds up to a great conservative victory in a broader sense. It produced "alienation", disinterest for collective solutions and a general "I give up" atitude. This well-financed and organized conservative machine cornered the niche-thematic center-left (unable to show a nation-wide project) and was able to achieve electoral victory.

Trump's victory in 2016 was a result of a longstanding process. The growth of the conservative right in the US is not a recent phenomenon, but became clear during the Tea Party's rise among the Republican Party. The Tea Party, boosted by millionaires like the Koch brothers, looked like the new boys in town. In 2016, in a new plot twist, Trump beat both old Republicans (like Jeb Bush) and the Tea Party. Trump first appeared as the unlike candidate then as an unlike president. Lastly, he became the unpredictable president. But the story of Hillary's defeat had begun years earlier.

Let us remember that Barack Obama won the election by almost 10 million vote difference from Senator John McCain (70 to 60 million). At that time, several analysts highlighted important elements, such as his weak coalition, an emerging "white working class" and their relationship with the right-wing candidates in the mid-west and the northernwest (recently named "Rust Belt").

Trump is often referred to as the candidate that concentrated discontent voters, mainly those visibly affected by Democrat's pro-globalization policy. Some point to the loss of votes of the Democrats as a decisive factor and not necessarily to the growth of the Republican candidate. Several reports point to the rather defining role of abstention, alienation and denial of politics from the white working class in comparison with the role of these people joining the far right. A recent Pew Charitable's Trust Economic Mobility Project survey indicate the white working class as the most pessimistic and alienated group of American society. ${ }^{5}$

"Allienated" does not necessarily capture what happened since it is a very passive term. These people actually decided to distance themselves from politics. Neoconservatives were victorious during this process since the idea that government is part of the problem rather than the solution (as in Reagan's famous

5. A summary of the study can be seen at this link: <http://www.theatlantic.com/politics/archive/2011/05>. 
phrase) seemed to have prevailed. On this line of thought, more important than having a "good government" is more to have "less government".

After all, Trump's campaign had a peculiarity: it was relatively cheap. Trump raised less than Hillary. This repeated, on a larger scale, what had happened on the last election. Obama had always raised more than his Republican competitors, and perhaps precisely because of this, he had always been Wall Street's preferred candidate. Trump spent little, skillfully exploring the fact that his aggressive, eccentric style as well as his position as an outsider would give him the spotlight without the need to pay for them it. In addition, there are indications that psychometrics and big data techniques made Trump's campaign more focused and effective, saving resources to transmit his messages to the electorate. Republicans had well-prepared teams to explore the rules in pursuit of more delegates at the electoral college (such as redesigning of districts) and not to aim for the majority of popular votes. In short, if on "demand" side it seemed to be a fertile field, on the other hand, on the supply side, the initiative of the ultra-right was far more articulate than that of its opponents.

The subject of appeals is also important to address. In fact, there are also costs of political campaigns outside of the usual campaign period and these resources are spent in different ways. Numbers compiled by Open Secrets ${ }^{6}$ show a steady increase in the cost of campaigning over the past 60 years. The most relevant element of tables and curves is a turning point on the 2000s. There is a gigantic increase in both presidential and legislative campaigns. Congressional (federal and state), state and local government campaign spending have been multiplied by 50 . As a result of this escalation, control groups gained more importance than the electorade's own choice of candidates. A huge volume of resources - including "dark money" - is employed to destroy candidacies even before they are born and to create allegedly spontaneous and popular political "celebrities" and "civic campaigns" with support of campaigns diffused on radio, TV billboards etc.

A book by Jane Mayer describes the ways in which money from conservative billionaires shapes the political environment by building a political current for the "masses" from scratch (Mayer, 2016).

"The business of America is business" is a phrase attributed to a former US president. The election business is increasingly speculative and dominated by sophisticated professionals and techniques. It has progressively become a fight for large animals. Ironically, the little animals have only the consolation prize of filling some spaces of the system with more "diversity". While they conquer pulpits, these smaller politicians only scratch at the big decisions from those who 
really shape the country. Perhaps the great move of the far-right is to create two disputes: one real, but almost invisible, and another fussy, but not very effective.

\section{REFERENCES}

BRITTANY, S. Who helped Trump most in the 2016 presidential election? Nonvoters, Pew Study says. Fortune, 08 Oct. 2018. Disponível em: <http:// fortune.com/2018/08/09/nonvoters-trump-presidency-pew-study/>.

EDITORIAL. O retrocesso de Trump. O Globo, 9 nov. 2016. Disponível em: <http://oglobo.globo.com/mundo/the-retrocesso-com-trump-20436979>.

GUIMARÃES, L. - Hillary, a assassina. O EstadodeS. Paulo, 21 nov. 2016. Disponível em: <http://cultura.estadao.com.br/noticias/geral,hillary-a-assassina,10000089549>.

KAZAN, O. People voted for Trump because they were anxious, not poor. The Atlantic, 23 Apr. 2018. Disopnível em: <https://www.theatlantic.com/ science/archive/2018/04/existential-anxiety-not-poverty-motivates-trumpsupport/558674/>.

MAYER, J. Dark money: the hidden history of the billionaires behind the rise of the radical right, United States: Doubleday, 2016.

ROSSI, C. Por que o Brasil vota Hillary. Folha deS. Paulo, 6 nov. 2016. Disponível em: <http://www1.folha.uol.com.br/colunas/clovisrossi/2016/11/1829754-porque-o-brasil-vota-hillary.shtml>.

TROYJO, M. Eleição dos EUA deixa o mundo à beira de um ataque de nervos. Folha de S. Paulo, 2 nov. 2016. Disponível em: <http://www1.folha.uol.com.br/ colunas/marcostroyjo/2016/11/1828577-eleicao-nos-eua-deixa-mundo-a-beirade-um-ataque-de-nervos.shtml>.

\section{COMPLEMENTARY BIBLIOGRAPHY}

BONVILLIAN, W. B. Donald Trump's voters and the decline of American manufacturing. Issues in Science and Technology, v. 32, n. 4, 2016.

BROWNSTEIN, R. The white working class: the most pessimistic group in America. The Atlantic, 27 May 2011. Disponível em: <https://www.theatlantic. $\mathrm{com} /$ politics/archive/2011/05/the-white-working-class-the-most-pessimisticgroup-in-america/239584/>.

BUM, P. New data makes it clear: Nonvoters handed Trump the presidency. TheWashington Post, 8Aug. 2018. Disponívelem: $<$ https://www.washingtonpost. com/news/politics/wp/2018/08/09/new-data-makes-it-clear-nonvoters-handedtrump-the-presidency/?noredirect=on\&utm_term $=.396 \mathrm{~d} 4215 \mathrm{~cd} 74>$. 
CHOI, D. Hillary Clinton: I won the places that are dynamic, moving forward, while Trump's campaign was looking backwards. Businers Insider, 13 Mar. 2018. Disponível em: <https://www.businessinsider.com/hillary-clinton-says-trumpwon-backwards-states-in-2016-2018-3>.

DAVIS, M. Reflections on the election. The Rag Blog, 17 Nov. 2016. Disponível em: <www.theragblog.com/mike-davis-reflections-on-the-election>.

. The great God Trump and the white working class. Catalyst, v.1, n. 1, 2017. Disponível em: <https://catalyst-journal.com/vol1/no1/great-god-trump-davis>.

. Donald Trump may have won - but this is no right - Wing Revolution. In These Times, 17 Aug. 2018. Disponível em: <http://inthesetimes.com/ article/19642/not-a-revolution-yet-donald -trump-hillary-clinton-exit-polls>.

GREENBERG, S. The democrat's working-class problem is worse than we think. The American Prospect, 7 June 2017. Disponível em: <https://prospect.org/ labor/democrats-working-class-problem/>.

GURLEY, L. K. 7 pundits who spread the myth of Trump's working-class voter base, AlterNet, 11 July 2017. Disponível em: <https://www.alternet. org/2017/07/7-pundits-who-spread-myth-trumps-working-class-voter-base/>.

ROSENTIEL, T. The party of nonvoters. Pew Research, 29 Oct. 2010. Disponível em: <https://www.pewresearch.org/2010/10/29/the-party-of-nonvoters/>.

SILVER, N. The mythology of Trump's working class support. Five Thirdy Eigth, 3 May 2016. Disponível em: <https://fivethirtyeight.com/features/themythology-of-trumps-working-class-support/>.

THE CONVERSATIONS. Psychographics: the behavioral analysis that helped Cambridge Analytics know voters' minds. Rawstory, 22 Mar. 2018. Disponível em: <https://www.rawstory.com/2018/03/psychographics-behavioral-analysishelped-cambridge-analytica-know-voters-minds $>$.

THE DATA TEAM. Where Donald Trump's support really comes from. The Economist, 10 July 2018. 
